\title{
Pemanfaatan Limbah Rambut Manusia sebagai Media Tanam Hidroponik Substrat pada Kailan
}

\author{
Niken Pusparini1), Dwi Harjoko2), Retna Bandriyati Arniputri²)
}

\begin{abstract}
This study aims to examine the use of human hair waste as a substrate hydroponic media in enhancing scientific innovation and agricultural development. This research was conducted in a greenhouse, Faculty of Agriculture, Sebelas Maret University, Surakarta, from July 2018 to October 2018. This experimental using a completely randomized design (CRD) method with one treatment factor and 14 levels repeated 4 times. The treatment includes washing hair waste (water, $\mathrm{NaOH}$ and detergent) and a combination of hair waste: husk charcoal $(1: 3 ; 1: 2$ and 3 : 1). In this study, the control treatment used sand media. Observation variables observed were leaf area index, number of leaves, plant height, stem diameter, root length, root weight, root volume, fresh weight and dry weight of plants. Data acquisition was analyzed by analysis of variance and if there were significant differences, further testing was carried out with Duncan Multiple Range Test (DMRT) at the level of $5 \%$. The results showed that human hair waste was less optimal as an alternative medium for hydroponic substrate systems. Treatment of hair waste: combination of $1: 3$ husk charcoal in all washings gives the highest average yield on all observation variables. In all washing treatments (Water, $\mathrm{NaOH}$ and detergent) the highest average yield was dominated by washing using detergent ie leaf area index $(55.35 \mathrm{~cm} 2)$, root volume $(1.19 \mathrm{ml})$, fresh weight $(22.03 \mathrm{~g})$ and dry weight $(2.83 \mathrm{~g})$.
\end{abstract}

Keywords: Baby Kailan, Human hair waste, husk charcoal

\section{PENDAHULUAN}

Rendahnya konsumsi masyarakat akan sayur didukung oleh rendahnya pengetahuan masyarakat akan ragam sayuran serta pola pikir masyarakat dalam budidaya tanaman yang masih terpaku pada sistem konvensional yang memerlukan lahan luas (WFP 2017). Salah satu sayur yang memiliki nilai gizi dan ekonomi tinggi dan masih sedikit orang ketahui adalah Kailan (Brassica alboglabra) atau yang dikenal dengan Chinese kale. Chandra-Hioe et al. (2017) menyatakan bahwa Kailan memiliki kandungan pro vitamin A yang tinggi. Vitamin A sangat penting untuk pertumbuhan dan perkembangan fungsi serta kekebalan tubuh manusia. Urban farming, dengan hidroponik dapat menjadi alternatif dalam mengatasi masalah lahan.

Hidroponik merupakan sistem budidaya menggunakan media selain tanah (soilless culture). Sarinah (2016) menyatakan bahwa sistem budidaya secara hidroponik mengandalkan air dengan kandungan nutrisi lengkap untuk menunjang pertumbuhan dan perkembangan tanaman. Keunggulan sistem hidroponik selain hemat tempat juga dapat dipanen sepanjang tahun. Sistem hidroponik juga dapat menjadi solusi permasalahan kemunduran sifat tanah akibat penanaman sayuran sejenis secara berulang. Eksplorasi media hidroponik perlu dilakukan, salah satunya dengan penggunaan limbah rambut manusia sebagai media tanamnya. Penelitian oleh Zheljazkovs (2005) menyatakan bahwa rambut manusia mengandung $\mathrm{N}, \mathrm{P}$, $\mathrm{K}$ dan $\mathrm{Cu}$ namun belum tentu dapat menjadi nutrisi yang tersedia. Menurut Gupta (2014) menyatakan bahwa

1) Mahasiswa S1 Program Studi Agroteknologi, Fakultas Pertanian, Universitas Sebelas Maret

2) Staf Dosen Program Studi Agroteknologi, Fakultas Pertanian, Universitas Sebelas Maret

Author Contact: npuspa23@gmail.com limbah rambut dapat digunakan pada beberapa bidang seperti pertanian, aplikasi medis, bahan konstruksi hingga sebagai pengendalian dalam pencemaran lingkungan. Negara China, India dan USA telah mengelola rambut manusia sebagai pupuk dan pestisida. Berdasarkan informasi yang diperoleh, inovasi penggunaan limbah rambut sebagai media substrat hidroponik belum pernah dibuat dan dipublikasikan, oleh karena itu perlu dilakukan penelitian untuk menambah inovasi dalam ilmu pengetahuan maupun pembangunan pertanian yang nantinya dapat menjadi alternatif solusi untuk mengatasi limbah rambut.

\section{METODE PENELITIAN}

Penelitian dilaksanakan pada Juli sampai Oktober 2018, bertempat di greenhouse, Fakultas Pertanian Universitas Sebelas Maret Surakarta. Suhu rata-rata pada pagi hari $29^{\circ} \mathrm{C}$, siang $36,8^{\circ} \mathrm{C}$ dan sore $31,8^{\circ} \mathrm{C}$. Bahan yang digunakan dalam penelitian meliputi benih kailan varietas Winsa, media arang sekam, pasir (kontrol), limbah rambut manusia, nutrisi $A B$ mix, air, $\mathrm{NaOH}$, deterjen. Peralatan yang dipakai dalam penelitian adalah EC meter, $\mathrm{pH}$ meter, jerigen, gelas ukur, nampan, polibag berlubang ukuran $35 \mathrm{~cm}$, mistar, mikrometersekrup, leaf area meter.

Rancangan yang digunakan dalam penelitian adalah Rancangan Acak Lengkap (RAL) dengan satu faktor, terdiri dari 14 taraf yang diulang 4 kali ulangan sehingga terdapat 56 satuan percobaan. Perlakuan meliputi:
- (A) Rambut + Arang sekam 1:3 (cuci air)
- (B) Rambut + Arang sekam 1:1 (cuci air)
- (C) Rambut + Arang sekam 3:1 (cuci air)
- (D) Rambut + Arang sekam 1:3 (cuci $\mathrm{NaOH}$ )
- (E) Rambut + Arang sekam 1:1 (cuci $\mathrm{NaOH}$ )
- (F) Rambut + Arang sekam 3:1 (cuci $\mathrm{NaOH}$ )
- (G) Rambut + Arang sekam 1:3 (cuci deterjen)
- (H) Rambut + Arang sekam 1:1 (cuci deterjen) 
- (I) Rambut + Arang sekam 3:1 (cuci deterjen)

- (J) Rambut $100 \%$ cuci air

- (K) Rambut $100 \%$ cuci $\mathrm{NaOH}$

- (L) Rambut $100 \%$ cuci deterjen

- (M) Sekam 100\%

- (N) Kontrol (Pasir).

Pelaksanaan penelitian meliputi: persiapan media, persiapan bahan tanam, penyemaian, pembuatan larutan nutrisi, penanaman, pemeliharaan, panen. Peubah yang diamati meliputi variabel daun (Luas daun dan jumlah daun), batang (tinggi dan diameter batang), akar (panjang, berat dan volume), berat hasil (basah dan kering). Analisis data menggunakan ANOVA dan diuj lanjut dengan uji Duncan Multiple Range Test (DMRT) $5 \%$.

\section{HASIL DAN PEMBAHASAN}

\section{Akar tanaman}

Pengamatan yang dilakukan pada akar meliputi panjang akar, berat dan volume akar. Tabel 1 menunjukkan bahwa panjang akar pada komposisi 1:3 yang dicuci dengan air dan $\mathrm{NaOH}$ memiliki panjang akar yang lebih baik dibandingkan kontrol. Hal yang sama juga berlaku pada berat akar serta volume akar. Penelitian Zuyasna (2009) menjelaskan bahwa tekstur media menjadi salah satu faktor yang mempengaruhi keefektifan media tumbuh tanaman. Pertumbuhan akar dipengaruhi oleh media tumbuhnya. Perlakuan pencucian dengan menggunakan deterjen memiliki tekstur yang lebih halus dan licin. Rambut yang dicuci deengan $\mathrm{NaOH}$ lebih kasar.

Tabel. 1 Rerata pengamatan variabel akar pada kailan

\begin{tabular}{ccccc}
\hline $\begin{array}{c}\text { Pencucian } \\
\text { limbah } \\
\text { rambut }\end{array}$ & $\begin{array}{c}\text { Limbah } \\
\text { rambut: } \\
\text { Arang } \\
\text { sekam }\end{array}$ & $\begin{array}{c}\text { Valume } \\
\text { akar } \\
\text { (cm) }\end{array}$ & $\begin{array}{c}\text { Panjang } \\
\text { akar } \\
(\mathrm{cm})\end{array}$ & $\begin{array}{c}\text { Berat } \\
\text { akar } \\
(\mathrm{cm})\end{array}$ \\
\hline Air & $1: 3$ & 1,08 & 18,64 & 2,28 \\
& $1: 1$ & 0,09 & 3,91 & 0,21 \\
& $3: 1$ & 0,01 & 0,50 & 0,07 \\
& $1: 0$ & 0,12 & 4,14 & 0,18 \\
\hline $\mathrm{NaOH}$ & $1: 3$ & 0,96 & 20,36 & 1,32 \\
& $1: 1$ & 0,19 & 7,51 & 0,26 \\
& $3: 1$ & 0,11 & 4,09 & 0,09 \\
& $1: 0$ & 0,00 & 0,00 & 0,00 \\
\hline Deterjen & $1: 3$ & 1,19 & 16,78 & 1,59 \\
& $1: 1$ & 0,40 & 11,30 & 0,46 \\
& $3: 1$ & 0,00 & 0,00 & 0,00 \\
& $1: 0$ & 0,05 & 1,78 & 0,04 \\
\hline \multicolumn{2}{c}{ Pasir (Kontrol) } & 0,54 & 6,76 & 0,65 \\
\hline \multicolumn{2}{c}{ Arang sekam } & 1,96 & 25,84 & 2,28 \\
\hline
\end{tabular}

Pencucian pada penelitian ini di duga memberikan pengaruh pada sifat campuran media. Rambut dengan cuci $\mathrm{NaOH}$ lebih mudah bercampur dengan arang sekam. Rambut yang dicuci dengan selain $\mathrm{NaOH}$ lebih sulit bercampur dengan arang sekam.

Penelitian Toruan et al. (2013) menyebutkan bahwa membuat kombinasi komposisi media tumbuh dengan tepat dapat mempertahankan kelembapan dalam waktu yang relatif lama. Substrat yang terlalu lembap maupun terlalu porous tidak baik bagi tanaman karena dapat mengganggu penyerapan akar akan hara. Penggunaan arang sekam dapat menyediakan aerasi dan drainasi serta porositas yang baik sehingga dapat membantu tanaman dapat bebas membentuk akar. Sistem perakaran yang baik akan menjadikan tanaman dapat menyerap air serta nutrisi yang diberikan dengan optimal sehingga dapat disebarkan ke seluruh tubuh tanaman (Wibowo et al. 2017). Fauzi et al (2013) menjelaskan bahwa semakin panjang dan luas permukaan akar pada suatu tanaman, mengakibatkan maksimalnya serapan hara dan air yang diikuti peningkatan laju asimilasi sehingga dapat mengoptimalkan pertumbuhan tanaman. Pertumbuhan akar sendiri dapat dipengaruhi oleh konsentrasi oksigen terlarut yang ada dalam media tumbuh hidroponik. Konsentraasi oksigen yang tinggi menyebabkan media memiliki EC, $\mathrm{pH}$ dan suhu yang ideal sehingga maksimal dalam membantu pertumbuhan dan perkembangan tanaman.

\section{Batang tanaman}

Pengaruh perlakuan kombinasi komposisi media limbah rambut dengan arang sekam terhadap tinggi tanaman disajikan pada Tabel 2.

Tabel. 2 Rerata pengamatan variabel batang

\begin{tabular}{cccc}
\hline $\begin{array}{c}\text { Pencucian } \\
\text { limbah } \\
\text { rambut }\end{array}$ & $\begin{array}{c}\text { Limbah } \\
\text { rambut: } \\
\text { Arang } \\
\text { sekam }\end{array}$ & $\begin{array}{c}\text { Variabel Pengamatan } \\
\text { Tinggi } \\
\text { tanaman } \\
\text { (cm) }\end{array}$ & $\begin{array}{c}\text { Diameter } \\
\text { batang } \\
(\mathrm{mm})\end{array}$ \\
\hline Air & $1: 3$ & 10,25 & 0,67 \\
& $1: 1$ & 4,13 & 0,15 \\
& $3: 1$ & 0,88 & 0,02 \\
& $1: 0$ & 5,25 & 0,17 \\
\hline $\mathrm{NaOH}$ & $1: 3$ & 11,31 & 0,82 \\
& $1: 1$ & 4,56 & 0,24 \\
& $3: 1$ & 2,63 & 0,16 \\
& $1: 0$ & 0,00 & 0,00 \\
\hline Deterjen & $1: 3$ & 12,13 & 0,68 \\
& $1: 1$ & 8,81 & 0,40 \\
& $3: 1$ & 0,00 & 0,00 \\
& $1: 0$ & 2,31 & 0,08 \\
\hline \multicolumn{2}{c}{ Pasir (Kontrol) } & 7,94 & 0,28 \\
\hline \multicolumn{2}{c}{ Arang sekam } & 14,31 & 0,85 \\
\hline
\end{tabular}

Hasil pencampuran berbagai kombinasi komposisi baik yang dicuci dengan air, $\mathrm{NaOH}$ maupun deterjen memberikan karakter yang berbeda pada pengaruhnya terhadap pertumbuhan tanaman. Penelitian Adhitya (2014) menjelaskan bahwa pencampuran serat aren dan arang sekam sulit tercampur. Rongga akan banyak terbentuk sebagai akibatnya. Rongga tersebut membuat kandungan air mudah menguap. Kombinasi komposisi limbah rambut: arang sekam 3:1 memberikan pengaruh hasil terendah terhadap tinggi tanaman, bahkan menyebabkan kematian. Arang sekam yang sedikit, diduga justru membuat rambut membentuk ruang udara yang lebih banyak. Ruang pori yang besar membuat kelembapan tidak stabil, media akan cenderung basah apabila tergenang dan akan cepat hilang akibat menguap. Yamamura (1997) cit Pokluda 2009 menyebutkan bahwa tanaman herba dengan daun yang menyebar lebih mungkin menginvestasikan sebagian besar bahannya ke jaringan batang untuk menjaga stabilitas fisiologis dan struktural. 


\section{Daun tanaman}

Irianto (2003) menunjukkan semakin meningkatnya luas bidang penerimaan cahaya, menyebabkan semakin besarnya kemungkinan fotosintat yang terbentuk. Fotosintat yang dihasilkan akan ditranslokasikan ke berbagai bagian dan digunakan untuk pertumbuhan dan perkembangan tanaman dengan menghasilkan bagian tanaman dan terakumulasi dibeberapa organ tanaman yaitu akar, batang daun dalam bentuk berat segar dan kering (Arguzen 2009). Luas daun pada perlakuan limbah rambut: arang sekam dengan pencucian air dan deterjen berbeda nyata pada komposisi 1:3 dan 1:1, sedangkan perlakuan limbah rambut: arang sekam pencucian $\mathrm{NaOH}$ memberikan pengaruh yang sama pada semua perbandingan komposisi.

Rata-rata luas daun tertinggi ditunjukkan oleh perlakuan komposisi limbah 1:3 dengan pencucian deterjen, $\mathrm{NaOH}$ dan air. Luas daun yang lebar menjadikan cahaya mampu diterima lebih banyak oleh tanaman untuk membantu proses fotosintesis. Menurut Samadi (2013) cit Alhadi et al. (2016) faktor cahaya matahari mampu mempengaruhi pertumbuhan kailan, semakin besar intensitas cahaya yang diterima akan mempercepat proses pembentukan organ vegetatif dan generatif tanaman. Menurut Liu dan Stützel (2004) bahwa komponen pertumbuhan dan hasil tanaman hortikultura adalah ketebalan daun. Dia melaporkan bahwa daun yang lebih tebal biasanya lebih padat akan klorofil dan protein yang lebih tinggi persatuan luas daun karena memiliki kapasitas fotosintesis yang lebih baik dari pada daun yang tipis. Rata-rata luas daun dapat dilihat pada Tabel 3 berikut.

Tabel. 3 Rerata pengamatan variabel daun

\begin{tabular}{cccc}
\hline $\begin{array}{c}\text { Pencucian } \\
\text { limbah } \\
\text { rambut }\end{array}$ & $\begin{array}{c}\text { Limbah } \\
\text { rambut: } \\
\text { Arang } \\
\text { sekam }\end{array}$ & $\begin{array}{c}\text { Variabel } \\
\text { Jumlah } \\
\text { daun } \\
\text { (helai) }\end{array}$ & $\begin{array}{c}\text { Luas daun } \\
\left(\mathrm{cm}^{2}\right)\end{array}$ \\
\hline Air & $1: 3$ & 5,63 & 39,8 \\
& $1: 1$ & 1,13 & 7,2 \\
& $3: 1$ & 0,38 & 3,2 \\
& $1: 0$ & 1,50 & 14,9 \\
\hline $\mathrm{NaOH}$ & $1: 3$ & 6,00 & 47,3 \\
& $1: 1$ & 2,75 & 12,7 \\
& $3: 1$ & 1,88 & 13,6 \\
& $1: 0$ & 0,00 & 0 \\
\hline Deterjen & $1: 3$ & 5,50 & 55,4 \\
& $1: 1$ & 4,13 & 23,0 \\
& $3: 1$ & 0,00 & 0 \\
& $1: 0$ & 0,75 & 6,0 \\
\hline \multicolumn{2}{c}{ Pasir (Kontrol) } & 7,13 & 23,6 \\
\hline \multicolumn{2}{c}{ Arang sekam } & 8,38 & 52,6 \\
\hline
\end{tabular}

Penelitian minggu ke tiga pada beberapa perlakuan ditemukan jamur tumbuh pada media tanam. Pencucian menggunakan deterjen di duga mengandung desinfektan yang mampu menghalangi jamur untuk tumbuh pada campuran media tanam. Tekstur halus dan lembut rambut dengan cuci deterjen diduga membuat limbah rambut cuci deterjen memiliki sifat tidak mudah menggumpal, sehingga membuat akar mudah menembus media tanam. Jamur tidak hanya tumbuh pada media yang memiliki rongga namun juga pada media yang terlalu memadat.

Daya serap akar yang baik memberikan dampak pada pembentukan bagian tanaman, pertumbuhan dan juga hasil. Jumlah daun merupakan gambaran dari hasil fotosintesis yang terjadi, dapat mengalami fluktuasi kuantitas yang dipengaruhi oleh aktifitas luar. Salah satunya adalah serangan organisme penggangu tanaman seperti ulat. Serangan ulat daun sangat dirasakan dampak kerugiannya pada sayuran yang dimanfaatkan daunnya. ulat daun dapat menyebabkan kerusakan berat dan dapat menurunkan produksi kailan sebesar $70 \%$, terlebih kailan merupakan sayuran yang diambil untuk dimanfaatkan batang dan daunnya (Purwanti 2011).

\section{Berat hasil}

Berat segar merupakan hasil pengukuran dari berat segar biomassa tanaman sebagai akumulasi bahan yang dihasilkan selama proses pertumbuhan (Buntoro 2014). Peningkatan bobot segar total kailan merupakan total seluruh pertumbuhan dari bagian-bagian tanaman tersebut. Variabel berat segar digunakan sebagai parameter proses tumbuh tanaman dan juga sebagai parameter kualitas hasil. Perhitungan berat kering tanaman atau biomassa bertujuan untuk mengetahui efektifitas proses fotosintesis suatu tanaman karena dapat menunjukkan banyaknya bahan organik yang mampu dibentuk oleh tanaman.Bobot total segar dan berat kering pada semua perlakuan memiliki hasil tertinggi terdapat pada perlakuan kombinasi limbah rambut: arang sekam 1:3. Hasil pengamatan dapat dilihat pada Tabel 4.

Tabel. 4 Rerata pengamatan variabel daun

\begin{tabular}{|c|c|c|c|}
\hline \multirow{2}{*}{$\begin{array}{l}\text { Pencucian } \\
\text { limbah } \\
\text { rambut }\end{array}$} & \multirow{2}{*}{$\begin{array}{l}\text { Limbah } \\
\text { rambut: } \\
\text { Arang } \\
\text { sekam }\end{array}$} & \multicolumn{2}{|c|}{ Variabel Pengamatan } \\
\hline & & $\begin{array}{c}\text { Jumlah } \\
\text { daun }\end{array}$ & Luas daun \\
\hline \multirow[t]{4}{*}{ Air } & $1: 3$ & 5,63 & 39,8 \\
\hline & $1: 1$ & 1,13 & 7,2 \\
\hline & 3:1 & 0,38 & 3,2 \\
\hline & $1: 0$ & 1,50 & 14,9 \\
\hline \multirow[t]{4}{*}{$\mathrm{NaOH}$} & $1: 3$ & 6,00 & 47,3 \\
\hline & $1: 1$ & 2,75 & 12,7 \\
\hline & $3: 1$ & 1,88 & 13,6 \\
\hline & $1: 0$ & 0,00 & 0 \\
\hline \multirow[t]{4}{*}{ Deterjen } & $1: 3$ & 5,50 & 55,4 \\
\hline & $1: 1$ & 4,13 & 23,0 \\
\hline & 3:1 & 0,00 & 0 \\
\hline & $1: 0$ & 0,75 & 6,0 \\
\hline \multicolumn{2}{|c|}{ Pasir (Kontrol) } & 7,13 & 23,6 \\
\hline \multicolumn{2}{|c|}{ Arang sekam } & 8,38 & 52,6 \\
\hline
\end{tabular}

Hasil yang baik juga ditunjukkan pada media 100\% arang sekam. Semua perlakuan yang mengandung komposisi arang sekam lebih dominan mempunyai pertumbuhan yang lebih baik dibandingkan kombinasi komposisi lainnya, pada semua perlakuan 
pencucian.Perbandingan komposisi yang pas dapat menunjang pertumbuhan tanaman dengan sangat baik. Komposisi yang didominasi oleh limbah rambut cenderung memberikan hasil yang kurang optimal dibandingkan media yang lebih banyak arang sekamnya. Sukawati (2010) mengatakan bahwa pada sistem tanah yang memiliki kerapatan gumpalan tanah dapat menurunkan pertumbuhan akar. Sedikit banyaknya ketersediaan rongga media dapat menyebabkan gangguan pada akar dalam menembus media dan memperluas percabangannya. Penggunaan media arang sekam padi dapat menurunkan pertumbuhan alga pada kombinasi media perlit dengan arang sekam pada penelitian Awad et al. (2017) sehingga mampu menghasilkan sayuran daun yang aman untuk dikonsumsi manusia.

\section{KESIMPULAN}

Hasil penelitian menunjukkan tidak berbeda nyata sehingga tidak dapat didapatkan perlakuan terbaik, dan dapat disimpulkan bahwa campuran limbah rambut dengan arang sekam dapat digunakan sebagai substrat tanpa mempengaruhi hasil secara nyata.

\section{DAFTAR PUSTAKA}

[WFP] World Food Programme. 2017. Fokus Khusus Tren Konsumsi dan Produksi Buah dan Sayur: Buletin Pemantauan Ketahanan Pangan Indonesia (8).

Adhitya R, Samanhudi, Harjoko D. 2014. Pengaruh campuran pasir dan serat aren pada kailan (Brassica oleracea) dengan hidroponik substrat. J Agrosains 16(1); 19-24.

Aguzaen H. 2009. Respon pertumbuhan bibit stek lada (Piper nisrum L.) terhadap pemberian air kelapa dan berbagai jenis CMA. Agronobis 1(1):36-47.

Alhadi, Triyono S, Haryono N. 2016. Pengaruh penggunaan warna lampu neon terhadap pertumbuhan tanaman kailan (Brassica oleracceea) pada sistem hidroponik indoor. J Teknik Pertanian Lampung. 15(1):13-24.

Awad et al. 2017. Biochar, a potential hydroponic growth substrate, enhances the nutritional status and growth of leafy vegetables. J Cleaner Production.156: 581-588.

Buntoro Bagus H, Rogomulyo R \& Trisnowati S. 2014. Pengaruh takaran pupuk kandang dan intensitas cahaya terhadap pertumbuhan dan hasil temu putih (Curcuma zedoaria L). J Vegetalika 3(4): 29-39.

Fauzi R, Putra Susila E.T, Ambarwati E. 2013. Pengayaan oksigen zona perakaran untuk meningkatkan pertumbuhan dan hasil selada (Lactuca sativa L) secara hidroponik. J Vegetalika 2(4) : 63-74

Gupta Ankush. 2014. Human hair "waste" adn its utilization: gaps and possibiities. Journal of Waste Management. Volume 2014, Article ID 49801817. URL: http://dx.doi.org/10.1155/2014/498018

Liu, F. and Stützel, H. (2004), Biomass partitioning, specific leaf area, and water use efficiency of vegetable amaranth (Amaranthus spp.) in response to drought stress. Scientia Horticulturae (102) 1527.

Pokluda R, Kopta T. 2009. Evoaluation of Chinese broccoli under organic growing conditions. Agriculture and Environment (1): 5-10

Purwanti. 2011. Hama dan penyakit tanaman kailan (Brassica oleraceae). URL: http://cybex.pertanian.go.id/materipenyuluhan/deta il/3789.

Sarinah. 2016. Penambahan oksigen pada media tanam hidroponik terhadap pertumbuhan pakcoy (Brassica rapa). J Bibiet 1(1): 27-35 DOI: http://dx.doi.org/10.22216/jbbt.v1i1.1249

Sukawati. 2010. Pengaruh kepekatan larutan nutrisi organik terhadap pertumbuhan dan hasil baby kailan (Brassica oleracea var alboglabra) pada berbagai komposisi media tanam dengan sistem hidroponik substrat. [Skripsi].

Toruan AL, Kaseke OH, Kereh LF, Sendow TK. 2013. Pengaruh porositas agregat terhadap berat jenis maksimum campuran. J. Sipil Statik 1(3): (190-195).

Wibowo AW, Suryanto Agus, Nugroho A. 2017. Kajian pemberian berbagai dosis larutan nutrisi dan media tanam secara hidropoik sistem substrat pada tanaman kailan (Brassica oleracea L.) J Produksi Tanaman 5(7): 1119-1125.

Zheljazkov VD. 2005. Assessment of Wool Waste and Hair Waste as Soil Amendment and Nutrient Source. J Environ Qual 34: 2310-2317

Zuyasna, Zaitun, Alfina S. 2009. Pertumbuhan dan hasil tiga varietas mentimun (Cucumis sativus L.) pada medium hidroponik tertentu. J Agrista 13(3): 104112 